\title{
Durability of mitral valve reconstruction using the cosgrove edwards annuloplasty band at 5 years
}

\author{
P Risteski, E von Spreti, F Sipahi, U Stock, M Doss, A Moritz, A Zierer \\ From 23rd World Congress of the World Society of Cardio-Thoracic Surgeons \\ Split, Croatia. 12-15 September 2013
}

\section{Background}

In the past, questions have been raised, whether an open flexible annuloplasty band can reliably prevent recurrent mitral valve regurgitation. The purpose of this study was to evaluate the durability of mitral valve repair at midterm, using the Cosgrove-Edwards annuloplasty band in a homogenic patient cohort.

\section{Methods}

From January 2004 to December 2007, 157 consecutive patients with degenerative mitral valve disease were included in the study. All had quadrangular resection of a P2 prolapse and annuloplasty with a Cosgrove-Edwards annuloplasty band. Clinical and echocardiography followup was complete.

\section{Results}

There was no intraoperative or 30 day mortality. After a mean follow-up of $5.0 \pm 1.9$ years, survival was $94.3 \%$. At midterm, freedom from reoperations was $98.9 \%$, freedom from thromboembolism was $97.5 \%$ and freedom from endocarditis was $99.4 \%$. Echocardiography follow-up showed recurrent mitral valve regurgitation higher than grade 2 in two patients. Mean ejection fraction was $60.3 \pm$ $10.2 \%$, left atrial diameter was $42 \pm 7 \mathrm{~mm}$, mean gradient was $3.2 \pm 1.4 \mathrm{mmHg}$, effective orifice area was $3.3 \pm$ $1.3 \mathrm{~cm}^{2}$, mitral leaflet coaptation length was $7.5 \pm 1.9 \mathrm{~mm}$ and mitral leaflet tethering height was $6.2 \pm 2.3 \mathrm{~mm}$.

\section{Conclusion}

Mitral valve repair using the Cosgrove annuloplasty band for degenerative mitral valve disease provides an effective and durable form of reconstruction.

\footnotetext{
* Correspondence: petarristeski@me.com

Department of Thoracic and Cardiovascular Surgery, Johann Wolfgang Goethe University, Frankfurt am Main, Germany
}

Published: 11 September 2013

doi:10.1186/1749-8090-8-S1-0290

Cite this article as: Risteski et al: Durability of mitral valve

reconstruction using the cosgrove edwards annuloplasty band at 5 years. Journal of Cardiothoracic Surgery 2013 8(Suppl 1):O290.
Submit your next manuscript to BioMed Central and take full advantage of:

- Convenient online submission

- Thorough peer review

- No space constraints or color figure charges

- Immediate publication on acceptance

- Inclusion in PubMed, CAS, Scopus and Google Scholar

- Research which is freely available for redistribution

Submit your manuscript at www.biomedcentral.com/submit

\section{() Biomed Central}

